\title{
Tourists' expenditure behaviour: the influence of satisfaction and the dependence of spending categories
}

\author{
MARTA DISEGNA \\ Department of Accounting, Finance $\mathcal{E}$ Economics, Faculty of Management, \\ Bournemouth University, Executive Business Centre, 89 Holdenhurst Road, \\ Bournemouth, BH8 8EB, UK. E-mail: disegnam@bournemouth.ac.uk.
}

(Corresponding author.)

\begin{abstract}
LINDA OSTI
Competence Centre in Tourism Management and Tourism Economics (TOMTE) and School of Economics and Management, Free University of Bozen-Bolzano, Piazzetta dell'Università, 39031 Brunico (Bolzano), Italy. E-mail: linda.osti@unibz.it.
\end{abstract}

\begin{abstract}
A review of the literature shows that the relationship between satisfaction and tourism expenditure, as well as the dependence among different tourist expenditure categories, are under-researched topics. The aim of this study is twofold: first, to investigate the influence on tourism expenditure of tourists' satisfaction with the destination, correcting for the effect of some socio-demographic and trip-related variables; second, to study the dependence among tourist expenditure on the different tourist categories that create the overall expenditure for the trip. This study focuses on an analysis of the expenditure behaviour of a sample of international visitors who travelled in an area around the Dolomites in Northern Italy, adopting the doublehurdle model with the Heien and Wessells estimator. In discussing the results, policy implications and managerial issues for tourism destinations are presented.
\end{abstract}

Keywords: tourist expenditure; tourist satisfaction; double-hurdle model; spending behaviour; dependence among expenditure

JEL Classification: C19; D12; L83

Tourism has long been recognized as an instrument for local economic development and regeneration of rural areas, due to its ability to increase profits and

Our research was supported by STTOBS - South Tyrolean Tourism OBServatory - a research project by the Free University of Bolzano, Banca di Trento e Bolzano and Banca Intesa Sanpaolo. The authors are listed in alphabetical order since they contributed equally to the work. 
generate economic benefits to host regions and communities (Craggs and Schofield, 2009). In this context, understanding and measuring tourism expenditure are essential for those tourism destinations whose major source of income is based on tourism revenues (Hung et al, 2012). Although international tourism demand is principally analysed at the macro level, in which the unit of analysis is an aggregated data (such as total arrivals, nights spent at tourist accommodation and total tourist receipts), to measure and determine the depth of the economic benefits experienced by the destination it is necessary to analyse microdata in which individuals or households are the principal unit of analysis. In fact, the analysis of individual tourist expenditure and of visitor spending behaviour can play a crucial role in achieving a better understanding of the economic benefits that a destination experiences when engaging in tourism.

Research studies suggest that expenditure is influenced by a wide range of socio-demographic and economic variables, psychological variables, trip-related and destination-related variables (Gyte and Phelps, 1989; Godbey and Graefe, 1991; Davies and Morgan, 1996; Oppermann, 1997; Legoherel, 1998; Agarnal and Yochum, 2000; Downward and Lumsdon, 2000; Mok and Iverson, 2000; Downward and Lumsdon, 2003; Ryan, 2003; Lehto et al, 2004; Jang et al, 2004; Laesser and Crouch, 2006; Craggs and Schofield, 2009; Wang and Davidson, 2010; Kim et al, 2011), and by satisfaction (Anderson et al, 1994 cited in Zhang et al, 2010). In fact, a review of the literature on customer satisfaction reveals that satisfaction stimulates repeat visits, positive recommendations and thereby new customers, reputation enhancement, higher acceptance of price increases and consequently overall higher profitability (Anderson et al, 1994; Baker and Crompton, 2000; Kozak and Rimmington, 2000; Homburg et al, 2005; Munier and Camelis, 2013). However, so far no studies have specifically addressed the relationship between satisfaction with destination attributes and expenditure (Zhang et al, 2010).

Moreover, analyses at the micro level allow researchers to be closer to two fundamental economic consumer theories: the consumer choice theory (Pudney, 1989) and the neoclassical economic theory of consumer behaviour (Deaton and Muellbauer, 1980). In particular, the latter theory was reformulated by Syriopoulos and Sinclair (1993) to adapt it to the tourism field. This last theory suggests that, considering a single trip, it is unrealistic to assume that the expenditure of tourists on different expenditure categories (such as accommodation, transportation, shopping, food and beverages, other services) is independent. Nonetheless, after a review of the literature, we have observed a lack of research devoted to the analysis of dependence among the different tourist expenditure categories encountered during a trip.

Therefore, analysis of the influence of satisfaction and the interrelationship among different tourism expenditure categories is an essential step for tourism decision makers in setting adequate planning strategies and stimulating an increase in visitors' expenditure at the destination. In this context, after the correction of the effect of the socio-demographic and trip-related variables, this paper analyses and describes the characteristics of tourists' spending behaviour by investigating:

(a) the influence of satisfaction on tourism expenditure;

(b) the dependence among different tourist expenditure categories. 
Specifically, the study investigates visitors' expenditure divided into spending for transportation, accommodation, food and beverage, shopping, and other services such as museums, shows, entertainment, guided tours, language courses and so on. The data used for this study were retrieved from the 2011 Annual Survey conducted by the Bank of Italy (Banca d'Italia) entitled 'International Tourism in Italy'. Although the main aim of this survey is to monitor travel expenditure and length of stay of international tourists visiting Italy, the level of satisfaction with different aspects of the trip and the overall satisfaction were also investigated.

The results of this study are essential for destination managers who wish to have a clear understanding of the relationship between satisfaction and expenditure and the dependence among the tourism expenditure categories. This information provides destination managers and private tourism businesses with practical knowledge useful for the management of customer service and the strategic planning and packaging of accommodation, attractions and other tourism and non-tourism services. The results of this study can also guide tourism planners in expanding their market share by seeking visitors who will spend money on as many services as possible at the destination.

\section{Literature review}

\section{Customer satisfaction and expenditure}

A considerable body of literature in both general service management and more specifically in tourism and hospitality management has focused on customer satisfaction since the late 1970s. Over the years, satisfaction has been analysed from different perspectives and for different purposes. Several studies have demonstrated that customer satisfaction is capable of stimulating repeat visits, positive recommendations and consequently new customers, reputation enhancement, higher acceptance of price increases and higher profitability (Anderson et al, 1994; Baker and Crompton, 2000; Kozak and Rimmington, 2000; Homburg et al, 2005; Munier and Camelis, 2013). Satisfaction has been analysed in terms of satisfaction with the single services/products at the destination, with the destination, and with the holiday/trip as a whole. Although most satisfaction studies concentrate on single aspects of the tourism experience, it has been argued that satisfaction in tourism should be studied as a system process, in which the several stages of the trip (pre-trip services, services at the destination and transit route services) are analysed collectively (Neal and Gursoy, 2008). In the tourism and hospitality industry satisfaction has been further investigated for controllable items, such as standard of the services offered, cleanliness, availability of information and prices, and for uncontrollable items such as culture, scenery and weather. Nevertheless, some researchers argue that any satisfaction study on uncontrollable items is limiting because of the difficulty in taking any corrective actions when dissatisfaction with such items occurs. Additionally, most of these items are the underlying reasons for choosing a destination rather than causes of dissatisfaction, provided that there has been an adequate pre-holiday information search (Kozak and Rimmington, 2000).

Satisfaction has also been studied to improve the product/service and effec- 
tively design management and marketing strategies (Kozak and Rimmington, 2000; Munier and Camelis, 2013). Customer satisfaction has, finally, been seen as an indicator of destination competitiveness and performance (Enright and Newton, 2004; Alegre and Garau, 2010; Munier and Camelis, 2013).

As reported by Neal and Gursoy (2008), most satisfaction studies are based on expectation and perception models (Oliver, 1980), cognitive evaluation (Klaus, 1985; Chadee and Mattsson, 1996), congruity models (Sirgy, 1984), equity models (Oliver and Swan, 1989) and perceived overall performance (Fuchs and Weiermair, 2004; Thompson and Schofield, 2007). So far the issue of customer satisfaction, consumer expenditure and consequently firms' economic benefits remains only partially examined and Anderson (1996), Anderson et al (1994, 1997) and Anderson and Mittal (2000) can be considered the pioneers in studies related to the link between customer satisfaction and profitability. According to these authors, firms that invest in customer satisfaction will enjoy economic returns. The main conceptual rationale behind their studies is that high customer satisfaction should indicate loyalty for current customers, reduced price elasticities, insulation of current customers form competitive efforts, lower costs of future transactions, reduced failure costs, lower costs of attracting new customers and an enhanced reputation for the firm' (Anderson et al, 1994, p 55). Although further research (Anderson et al, 1997) has examined the differences in this nexus between goods and services, loyalty remains one of the pillars on which the theory of the satisfaction-profitability chain is based. However, in that respect, it is important to note that loyalty might not be as important to destinations as it is for other businesses or services (Kozak and Rimmington, 2000). Although past studies (Oliver and Burke, 1999; Hui et al, 2007) have demonstrated that tourists' overall level of satisfaction with the destination influences the intention to revisit, the dis/satisfaction with various components of the holiday experience (pre-trip services, services at the destination, transit route services) leads to overall dis/satisfaction (Neal and Gursoy, 2008), influencing future intentions (Kozak and Rimmington, 2000). Furthermore, although loyal customers mean more customers in general, lower impact of price fluctuations and less cost for the firm in attracting new customers due to positive word of mouth, in an industry, like tourism, affected by fixed capacity, are loyal (repeat) customers more likely to spend more at the destination? Past research has reported contradictory results (Oppermann, 1996; Alegre and Juaneda, 2006 cited in Zhang et al, 2010; Chang et al, 2013).

Along the continuum of the satisfaction-profitability chain, but with a different approach from Anderson et al (1994), Homburg et al (2005) investigated the relationship between customer satisfaction and willingness to pay. Based on equity theory, they hypothesized that "when customer experience elevated states of satisfaction, they perceive a high outcome of an exchange and therefore are willing to pay more ... because this still results in an equitable ration of outcome to input' (Homburg et al, 2005, p 85). The findings of their study revealed a positive relationship between consumer satisfaction and willingness to pay.

In the tourism literature, few studies have examined the relationship between consumer satisfaction and expenditure (Zhang et al, 2010) and there is the need to better understand the role of visitors' satisfaction in influencing an individual's expenditure patterns (Kim et al, 2010). In existing studies, satisfaction has 
been seen as a significant predictor of expenditure in the case of festival and events (Kim et al, 2010), at exhibitions (Zhang et al (2010), in the case of purchases at travel agencies (Chen and Chang, 2012), at theme parks (Bigné et al, 2005) and in the hotel industry (Kim and Cha, 2002). So far, the relationship between satisfaction with destination attributes and expenditure is under-researched, and in light of neoclassical theory a new approach to this issue must be taken.

\section{Visitors' expenditure: theories and models}

There is a substantial body of literature relating to tourism's economic impact at the macro level, but less is known about visitors' expenditure at a micro scale. As stated by Alegre and Pou (2004), studies at the micro level have several advantages: first, they are closer to theoretical economic consumer models; second, they preserve the choice by individuals not to spend any money for tourism services; third, they preserve the heterogeneity and diversity of individual consumer behaviour. More recently, Belenkiy and Riker (2013) underlined that the main advantages in using micro data lie in the fact that these data report the expenditure of individual travellers together with demographic, social or other characteristics that can be used to control (or profile) the units of analysis. Nonetheless, the main limitation is that it is not possible to model dynamic adjustments because the datasets are not time-series.

In a review of the literature, Lim (2006) found only nine studies, among the 124 analysed, in which ad hoc designed surveys were employed to take into exam individual economic units. More recently, Wang and Davidson (2010) identified and analysed 27 studies that used expenditure as the measure of individuals' demand for tourism. These studies clearly support the idea that the micro level needs to be studied further to fill a gap in the literature.

Most of the microdata studies investigating tourism expenditure have used ordinary least squares (OLS) estimation in linear regression models (Wang and Davidson, 2010; Brida and Scuderi, 2013; Wu et al, 2013). However, the presence of a high proportion of expenditure values equal to zero presents tourism spending as a non-negative (that is, left-censored) distribution. Thus, the OLS method may lead to inconsistent and bias parameter estimates (Maddala, 1983; Amemiya, 1984) since the normal assumption of the dependent variable is often unrealistic. To address the problem of zero expenditure, and provide a suitable estimation for censored dependent variables, the Tobit regression model (Tobin, 1958) has been applied in the tourism field. Leones et al (1998), Lee (2001), Zheng and Zhang (2011), Barquet et al (2011), Kim et al (2011), among others, estimate tourism expenditure applying the Tobit model.

A further evolution of the Tobit model is the 'double-hurdle' (Cragg, 1971) model. The main advantage of this model is that it enables the decision-making process to be split into two natural stages, or decisions, following consumer choice theory (Pudney, 1989): (a) the decision to spend (selection stage); and (b) the choice of how much to spend (outcome stage). These stages are modelled through two separate models, whereas in the Tobit model the two stages are treated as if they were generated from the same consumer decision process, assuming that the sets of independent variables influencing the selection stage are the same that influence, with the same direction and intensity, the outcome 
stage. The Cragg model assumes that the two decisions are independent. This implies that the model applied at the second stage estimates the average tourism spending using the data collected from a population in which individuals who do not spend are excluded by self-selection. The Heckman (1976) model allows the sample selection problem to be treated as a problem of omitted variables, and it corrects for bias in the estimation of the second stage equation by introducing a new variable - the inverse Mill's ratio - calculated on the basis of the estimations obtained through the first stage equation. In this way, the Heckman model allows for the error term of both equations to be correlated and the two decisions to be dependent. More recently, Heien and Wessells (1990) proposed an alternative formula of the Mill's ratio that allows all observations to be used in each stage, whereas in the Heckman model the zero observations are omitted from the second stage. Studies in which the double-hurdle model has been applied include Weagley and Huh (2004), who analysed leisure expenditure of retired and near-retired Americans' households, and Hong et al (1999) who investigated the travel expenditure patterns of elderly households in the USA. Recent applications of the Heckman model include Alegre et al's (2013) application to tourism participation and expenditure by Spanish households, and Jang and Ham's (2009) application to leisure travellers' expenditure, distinguishing between baby boomer senior households and older senior households in the USA. Finally, the double-hurdle model estimated by means of the Heien and Wessells two-step estimator has been adopted by Marzetti and Disegna (2012), Brida et al (2012; 2013a), and Brida et al (2013b).

In addition to consumer choice theory, according to which each decisionmaking process to purchase can be described as a two-step process, another important economic theory must be taken into consideration when modelling expenditure: the neoclassical economic theory of consumer behaviour (Deaton and Muellbauer, 1980). According to this theory, consumers are rational and wish to maximize their utility function by choosing among a set of available alternatives. Thus, the utility function can be described as the maximum satisfaction that consumers obtain from the consumption of various goods and services that they purchase, at a certain level of income (budget). In fact, when undertaking an expenditure, tourists first decide whether to incur such a cost by comparing their purchase with other opportunities in other industries; then they decide on the goods and services to buy based on the goods and services offered on the market and the budget available. Tourism expenditure is therefore a consumer choice, first between goods and services in various industries, and then between various expenditure in the tourism industry (Tribe, 2005; Zheng and Zhang, 2011).

Consumers are assumed to be able to rank goods and services in such a way that they can select the particular combinations for which their utility function takes the largest value, at a certain level of income (budget). Furthermore, the consumer's utility function is 'separable'. The separability, and in particular the assumption of weak separability, assumes independence only among groups of commodities instead of among individual commodities. Focusing on tourism, this implies (Syriopoulos and Sinclair, 1993) that: first, tourists allocate their budget between tourism activities and other goods and services; second, tourists allocate their tourism budget to a specific or multiple destinations, including 
the home country; third, tourists choose how to allocate their tourism budget among various goods and services offered by the selected destination(s). Therefore, considering one single trip, it is realistic to assume that the different tourist expenditure categories are dependent on each other. Until now, little attention has been paid to analysis of the dependence among different tourist expenditure categories; the studies of Bilgic et al (2008) and Divisekera (2010) represent two important exceptions in the tourism demand literature.

\section{Data and structure of the questionnaire}

\section{The survey}

The Bank of Italy (Banca d'Italia) annually conducts a survey entitled 'International Tourism in Italy' to determine the tourism balance of payments. The main aim of this survey is to monitor the travel expenditure and length of stay of inbound and outbound visitors from/to Italy. Travel expenditure includes the total consumption of goods and services in the country visited divided into five expenditure categories. The inbound-outbound frontier survey is the technique adopted for the collection of the data.

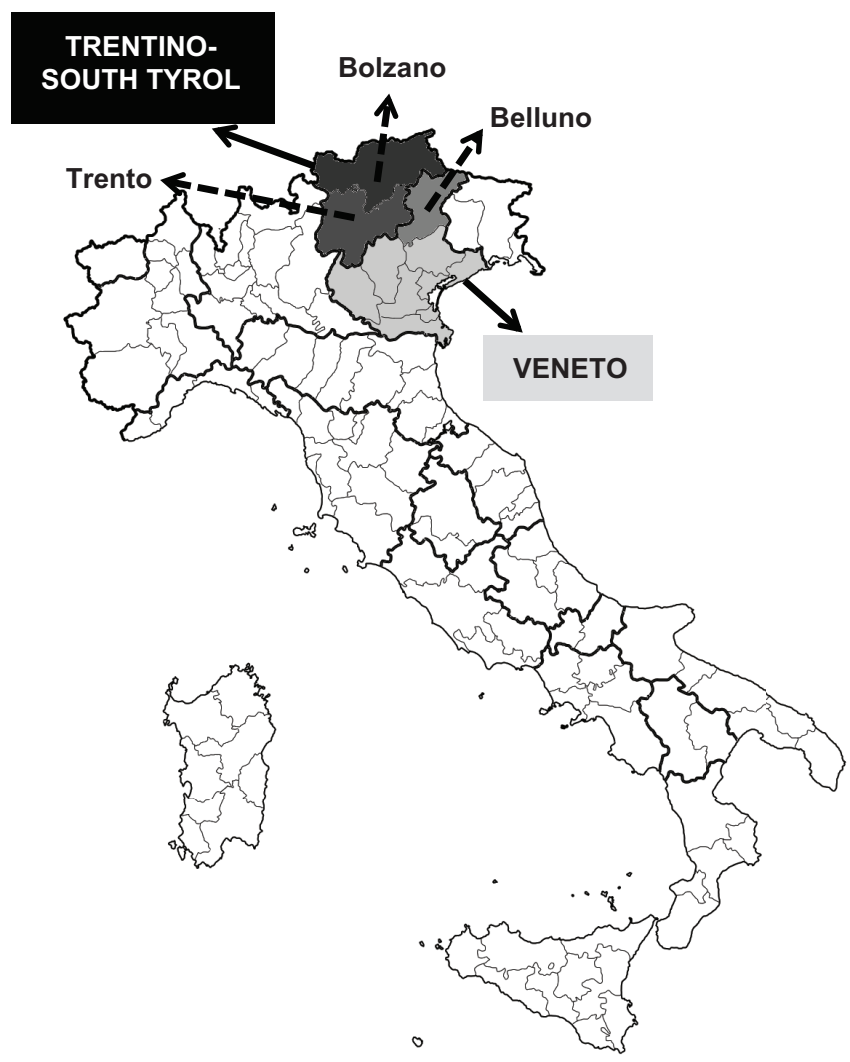

Figure 1. Study site. 
The stratified sampling method is applied (using different types of stratified variables per each type of frontier) and face-to-face interviews are carried out at national borders (including highways, railway, airports and harbours). Sampling is done independently at each type of frontier. Tourists are interviewed at the end of the trip, when they are returning to their place of habitual residence. Interviews are conducted at different times of the day, during both working days and holidays, and month by month, with a fixed number of interviews per each period of survey. The questionnaires are anonymous and are offered in 14 languages.

The questionnaire can be divided into four main sections: 1 . socio-demographic characteristics of the interviewee (gender, age, occupation and residence); 2. information on the trip (number of nights spent, type of accommodation, cities visited, means of transportation, motives, organization); 3. information on expenditure (total expenditure divided into different categories of expenditure, means of payment); 4 . level of satisfaction with different aspects of the trip and overall satisfaction with the destination.

In this study we focus on the 1,030 foreign visitors who visited the provinces of Bolzano, Trento and Belluno in 2011 (Banca d'Italia, 2011). The first two provinces compose the Trentino South Tyrol region, while Belluno is a province of the Veneto region. These three provinces are located in Northern Italy (see Figure 1) and are famous for the Dolomite range which stretches across all the three. Finally, we take into consideration only international visitors whose main purpose of trip is 'tourism, holiday and leisure'.

\section{Descriptive analyses}

The survey offers detailed information on the amount of money spent in the five main categories of a typical travel budget: (a) 'Accommodation' (hotel, apartment for rent, campsite, etc), which also includes expenditure on food and beverage on the accommodation premises; (b) 'Food and beverages' consumed outside the accommodation premises; (c) 'Internal transportation' in the visited destination, including purchase of fuel; (d) 'Shopping', including souvenirs, gifts, clothes, food and beverages, etc, purchased only for personal use; (e) 'Other services', like museums, shows, entertainment, guided excursions, language courses and so on.

The sample consists of $89.13 \%$ tourists (that is, people who spent at least one night in South Tyrol), and $10.87 \%$ day-visitors. During the trip, the great majority of the sample said they had incurred costs for food and beverages (85.92\%), internal transportation $(78.16 \%)$, shopping $(77.67 \%)$, and, as expected, on the trip as a whole (97.8\%). In contrast, only $39.71 \%$ of the sample said they had incurred costs for other services. When describing the expenditure behaviour of the whole sample (see Table 1 for the average and median amount spent per night per person), we can observe that visitors typically spent a large part of their travel budget on accommodation (about 43\%), spending on average $€ 42$ per night per person. This is followed by expenditure on food and beverages, which accounts for $19 \%$ of the total travel budget, with an average expenditure per night per person of $€ 19$, and shopping (18\% of the total travel budget and $€ 18$ spent on average per night per person). The least important expenditure categories are internal transportation and other services, which 
Table 1. Mean (median) expenditure by different tourism categories per night per person.

Item

Accommodation

Food and beverages

Transportation

Shopping

Other services

Total travel expenditure
Whole sample

$$
\begin{gathered}
42.24(30.00) \\
12.32(4.15) \\
18.62(8.33) \\
18.06(6.25) \\
7.14(0.00) \\
98.51(75.17)
\end{gathered}
$$

Sub-sample of spenders

$$
\begin{gathered}
47.39(35.00) \\
21.83(14.29) \\
15.76(6.67) \\
23.25(10.00) \\
17.99(9.18) \\
100.76(77.00)
\end{gathered}
$$

account for $13 \%$ and $7 \%$, respectively, with an average expenditure per night per person of $€ 12$ and $€ 7$.

Another important group of variables collected through the survey concerns the overall level of satisfaction with the destination and with the following aspects of the trip: hospitality and friendliness of the local inhabitants ('Friendliness'); cities and works of art ('Art'); landscape and natural environment ('Landscape'); hotels and other accommodation ('Accommodation'); 'Food and beverages'; price and cost of living ('Price'); quality and variety of products offered in stores ('Products sold'); information and tourist services ('Information'); safety of tourists ('Safety'). A 10-point Likert scale was used, with (1) indicating 'Very unsatisfied' and (10) 'Very satisfied'. Figure 2 displays the percentage distribution of the level of satisfaction per each observed item. The percentage of visitors who attributed a value lower than 6 to the different aspects of the trip is very low, with the exception of 'Price', which shows the lowest mean and median value (both approximately equal to 7).

On average (see Table A1 in the Appendix), tourists spent 9 nights in the

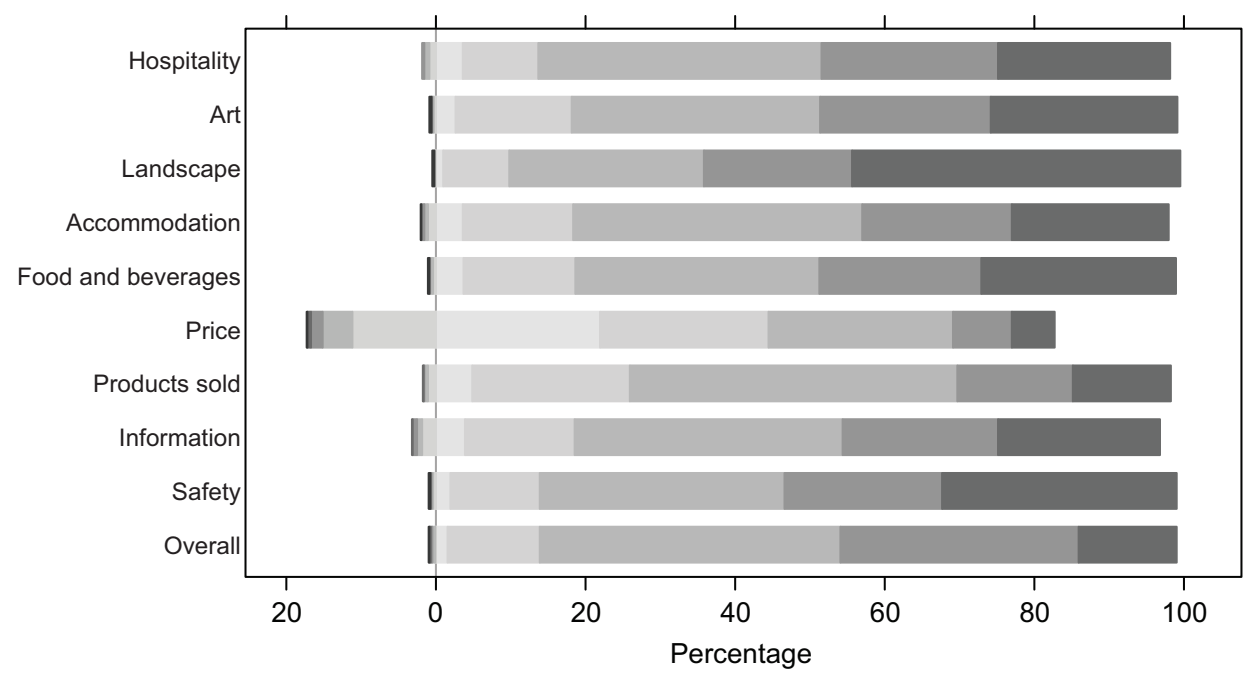

Very unsatisfied

$2 \square-3-4 \square 5-6$

Figure 2. Level of overall satisfaction and satisfaction with different aspects of the trip. 
Dolomite area, mainly visiting only one city during the trip (79\%) and travelling with other people (79\%). For approximately $22 \%$ of the sample, this was their first visit to Italy, while $42 \%$ had already been to Italy more than five times. Visitors came mainly from Germany (38\%), Austria (14\%) and other European countries (39\%), while only $9 \%$ came from a country outside Europe. Finally, about half of the sample was under 45 years of age.

\section{The econometric model}

In order to investigate (a) the influence of the satisfaction both on overall expenditure and on different expenditure categories, and (b) the dependence among different tourist expenditure categories, the Tobit model (Tobin, 1958), or one of its generalizations, can be adopted. In fact, this category of model is the most suitable when the dependent variable is non-negative, and thus essentially continuous over strictly positive values, and it also takes zero values with positive probability (that is, a non-trivial fraction of the population takes zero value). For this type of dependent variable, the use of the multiple regression model, estimated by using the well-known OLS method, would produce biased and inconsistent estimates of parameters (Maddala, 1983; Amemiya, 1984).

Another important characteristic of the expenditure is that the monetary value declared by the individual is the result of two possible processes, as suggested by consumer choice theory (Pudney, 1989): the individual decides whether or not to purchase something (selection stage) and then he or she decides how much money to spend on that purchase (outcome stage). Therefore, to observe a positive level of expenditure, two distinct hurdles must be cleared. In this context, it is preferable to adopt a two-stage generalization of the Tobit model, the double-hurdle model (Cragg, 1971). This model is performed through the estimation of two separate regression models: the selection stage is estimated by the Probit model in order to estimate the probability of spending or not spending on something; the outcome stage is estimated by the OLS regression model to estimate the average amount of money spent in a particular expenditure category. In this way, throughout the estimation of the double-hurdle model, we can obtain two different sets of relevant independent variables (one for each stage), whereas the estimation of the standard Tobit model identifies a single set of variables to measure the effect of both the selection and the outcome stage.

To avoid the problem of sample selection - defined as an omitted variable problem (Heckman, 1976) - in this study the estimator proposed by Heien and Wessells in the early 1990s is adopted (Heien and Wessells, 1990; see, for applications, Byrne et al, 1996; Manrique and Jensen, 1997). This estimator is called inverse Mill's ratio (MR) and it is calculated for each observation through the estimates obtained in the first stage - that is, through the estimation of the Probit model. Contrary to the traditional Heckman two-step estimator, the MR variable allows correcting the problem of sample selection using all the observations in each stage. Furthermore, the MR variable is incorporated into the set of explanatory variables used in the regression estimated at the second stage, playing a fundamental role in linking the two stages. 


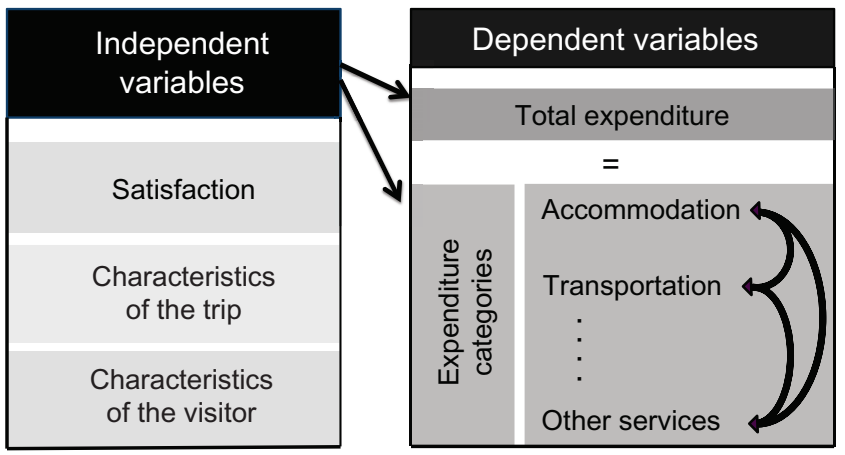

Figure 3. Schematic representation of research aims.

It is important to note that, if the estimated coefficient of the MR variable is not significantly different from zero, the decision to spend and the decision on how much money to spend are independent and the sample selection problem is unimportant; that is, the sample selection rule ensures that all potential observations are sampled, so that the Tobit model can be used instead of the double-hurdle model.

\section{The set of dependent and independent variables}

Six suitable censored models, one for the total tourist spending and one per each expenditure item ('Accommodation', 'Transportation', 'Food and beverages', 'Shopping', and 'Other services'), were separately estimated. Figure 3 schematically represents the aims of this study: to determine the influence of satisfaction on the tourist expenditure, taking into consideration also the influence of other independent variables listed and synthetically described in Table A1 of the Appendix, and to study the dependence among different tourist expenditure categories. This last aim has been analysed including among the set of independent variables the total travel expenditure allocated for a particular tourist expenditure category, excluding the one modelled. Notice that all variables regarding tourist expenditure (both dependent and independent) are per person per night and logarithmically transformed to handle more effectively possible non-linear relationships between the independent and dependent variables.

\section{Model results}

Since only $2.2 \%$ of the sample stated a zero value for the total visitor expenditure, the Tobit model was used to identify the determinants of the total expenditure. The five different expenditure categories were modelled using the double-hurdle model since it is interesting to estimate the selection and outcome stage separately thanks to the higher number of zero values.

All the models were estimated using White's robust standard variancecovariance matrix (White, 1980) to correct for possible heteroscedasticity of the error term. The backward results for the Tobit model are reported in Table 2, 
while Tables 3 and 4 present respectively the backward results for the first (selection) and second (outcome) stage of the five double-hurdle models estimated. The results of the first stage model (Table 3 ) are reported as marginal effects calculated at the median value of each explanatory variable (see Table A1 in the Appendix for the median values). Table 4 shows that MR is significant for each model, and this implies that the decisions (a) to spend or not to spend, and (b) how much to spend are dependent and can be explained by different sets of explanatory variables for each of the tourism expenditure categories considered. Furthermore, the significance of MR suggests that the double-hurdle model is appropriate.

\section{Influence of satisfaction on expenditure behaviour}

Satisfaction with specific characteristics of the destination is found to be significant in affecting visitors' expenditure behaviour in the willingness to spend, in the amount of money spent within the different expenditure categories and finally in the total budget spent.

As shown in Table 2, there is a strict correlation between satisfaction with landscape and prices and the total expenditure per person per day. Specifically, for a one-unit increase in satisfaction with the landscape we expect to see about a $7.6 \%$ increase in total visitor spending $\left(e^{0} .073 \approx 1.076\right)$. Similarly, a one-unit increase in satisfaction with prices produces about a $7 \%$ increase in total expenditure.

Satisfaction with different characteristics of the destination exerts a positive effect also on the willingness to incur an expenditure within the different spending categories. As shown in Table 3, satisfaction with safety positively affects the propensity to spend on accommodation, food and beverages, and shopping. Satisfaction with landscape positively affects expenditure on accommodation and transportation; satisfaction with food and beverage positively

Table 2. Determinants of total tourist spending (ln transformed).

Independent variables

Tobit model

Are you satisfied with the following aspects related to the trip?

Landscape

$0.073(0.03)^{\mathrm{a}}$

Price

$0.068(0.02)$

Characteristics of trip

Number of nights

$-0.033(0.01)$

First time in Italy

$-0.350(0.12)$

Italy visited up to 5 times

$-0.156(0.08)$

Cities in the Dolomite area

$-0.450(0.09)$

Characteristics of tourist

Austria

$-0.931(0.17)$

Outside EU

$0.307(0.16)$

Germany

$-0.294(0.08)$

Constant

$3.903(0.36)$

Notes: ${ }^{a}$ Estimated coefficients and robust standard errors in brackets. Number of observations $=959$; Wald $\operatorname{chi}^{2}(9)=261.11 ;$ prob $>\chi 2=0$; log pseudo-likelihood $=-$ 1454.9951; McKelvey and Zavoina's $R^{2}=0.240$. 


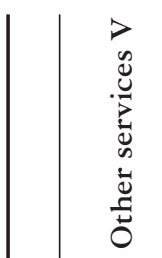

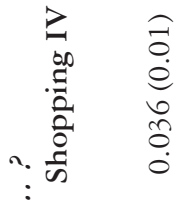

:

ริ

$\frac{2}{8}$

$\stackrel{5}{3}$

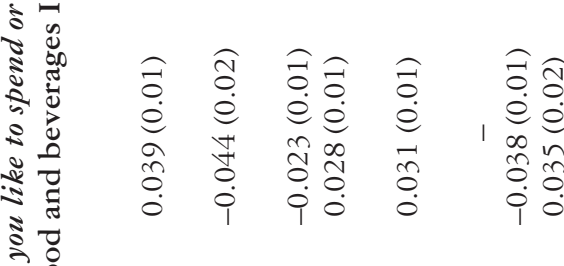

고

列

胥

$\stackrel{5}{8}$

政

ב⿱艹

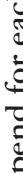

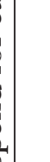

$-\frac{2}{\mathrm{~s}}$

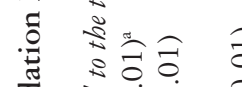

흫ํำ

e $巳 e$

กิ ণิ

:०0:

$\vec{a}$
$\dot{0}$
$\stackrel{\infty}{0}$
$\stackrel{0}{0}$

ฐ $\dot{0} 0$

눙

¿.ं

st

กิ่

बं

壱。

ํ.?

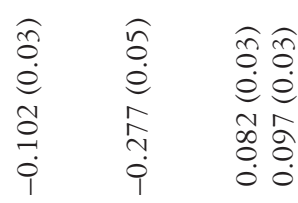

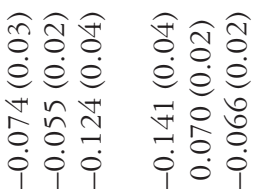

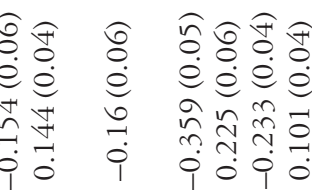

ํํㅅำ "I 气े 可家兹

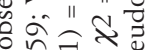
- $\approx \wedge$ ह

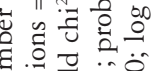

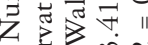
$\ddot{u}$ 议 च्ष्प्र

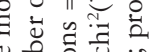
늘

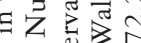
证 둥 o

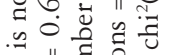

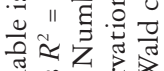

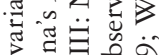
v

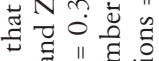

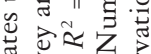

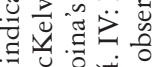

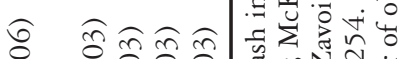
e $\dot{0} \circ 0$

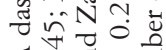

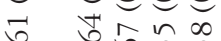

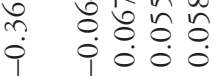
मे $\frac{\pi}{2} \approx$

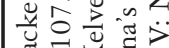
要 0 io 0

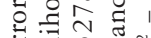

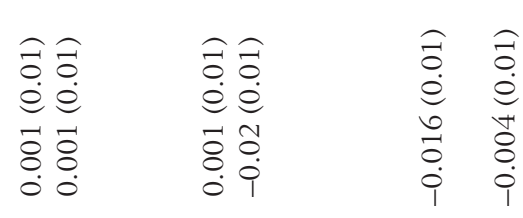

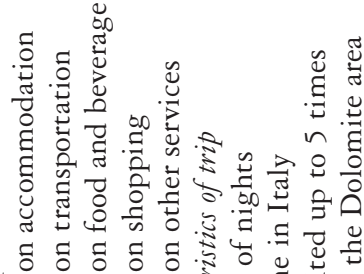

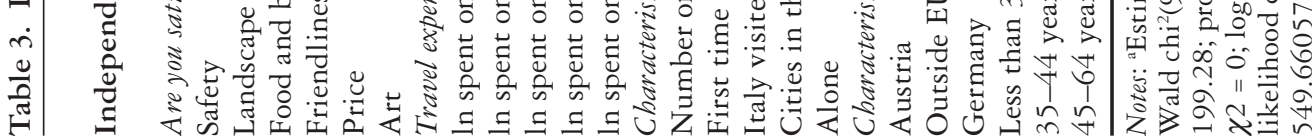

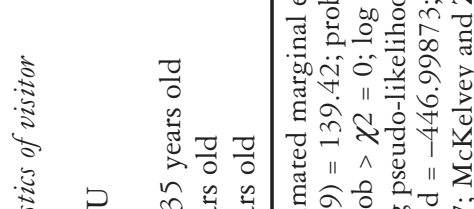

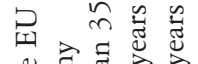

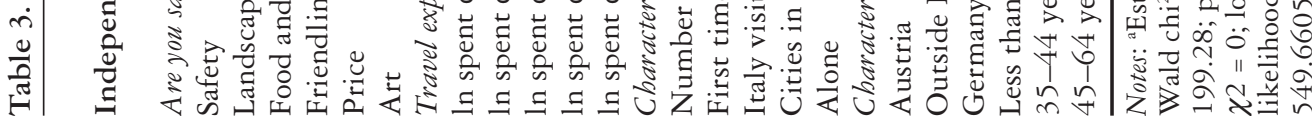

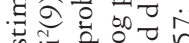

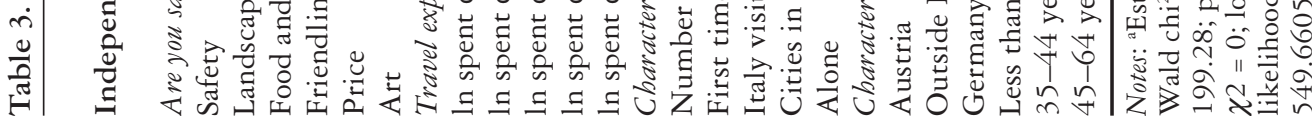

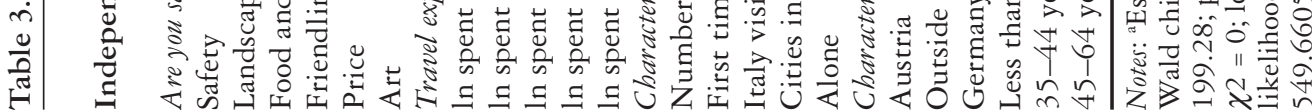




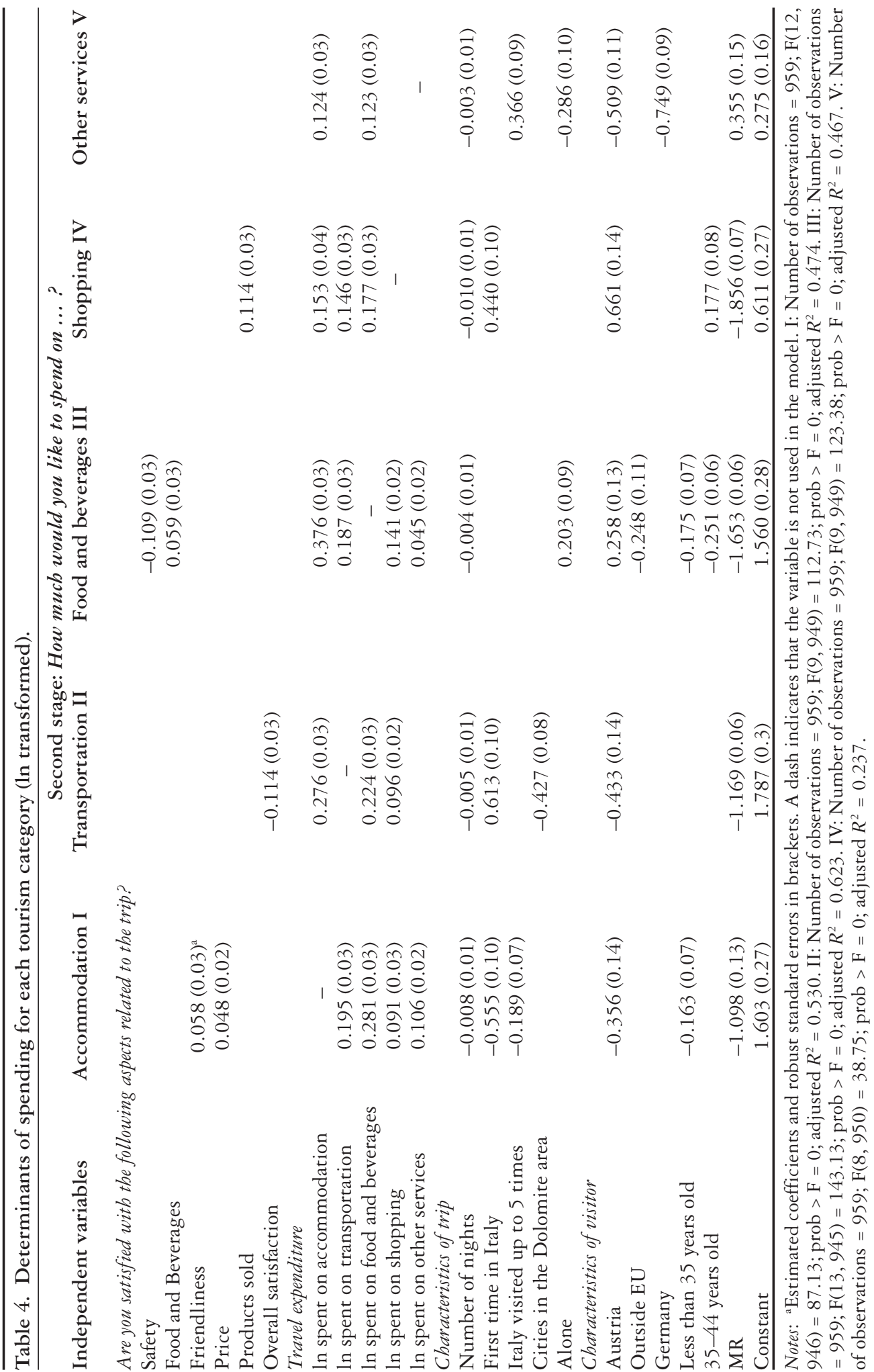


affects expenditure on transportation; finally, satisfaction with prices and arts positively affects the willingness to incur expenditure on transportation and food and beverages. However, satisfaction with certain characteristics of the trip can also exert a negative effect on the propensity to spend. In particular, satisfaction with the friendliness of the local inhabitants negatively affects the propensity to spend on accommodation and transportation; satisfaction with prices negatively affects the propensity to spend on food and beverage.

As regards the amount of money spent in the different product categories (see Table 4 for the estimated coefficients and Table 5 for the estimated percentage variation), the more visitors are satisfied with the food and beverages offered at the destination, the more they will spend on food and beverages; the more they are satisfied with the friendliness of the local inhabitants and with prices, the more they will spend on accommodation, and the more they are satisfied with the products available in the local stores and shops, the more they will spend on shopping. Nevertheless, as was the case for the propensity to incur an expenditure, satisfaction also exerts a negative effect on the amount of money spent in certain expenditure categories. In particular, the higher the satisfaction with safety, the lower the amount of money spent on food and beverages, and the higher the overall satisfaction, the lower the amount of money spent on transportation.

Table 5 reports the influence not only of satisfaction but also of dissatisfaction. In fact, whenever the model has determined a relationship between satisfaction and expenditure, it is possible to calculate the effect on spending due to both a unit increase and a unit decrease in the level of satisfaction. Specifically, a decrease in satisfaction with friendliness and price would determine a decrease in money spent on accommodation, a decrease in satisfaction with food and beverages determines a decrease in money spent on food and beverages, and, finally, a decrease in satisfaction with the products sold determines a decrease in money spent on shopping. As an illustration, if visitors are more satisfied with the products sold and move their evaluation from the mean value equal to 8 up to 9 , we observe a $12 \%$ increase in the average expenditure on shopping. Conversely, if the visitors are less satisfied with the products sold, reducing their satisfaction level to 7 , we observe an $11 \%$ decrease in the average expenditure on shopping.

\section{Dependence among different tourist expenditure categories}

As can be seen in Table 3, the willingness to spend on different expenditure categories is dependent on the expenditure in other product categories. In particular, visitors are more willing to incur an expenditure on accommodation if they have also incurred expenditure on food and beverages and internal transportation. Similarly, an expenditure on accommodation will determine the willingness to spend on internal transportation. Finally, visitors are more likely to spend on food and beverages if they have also spent on other services and accommodation, but they are less likely to spend on food and beverages if they have spent on shopping.

Also in terms of the amount of money spent in each expenditure category, we can observe (see Table 4 for the estimated coefficients and Table 6 for the estimated percentage variation) that the pairwise relations among almost all 

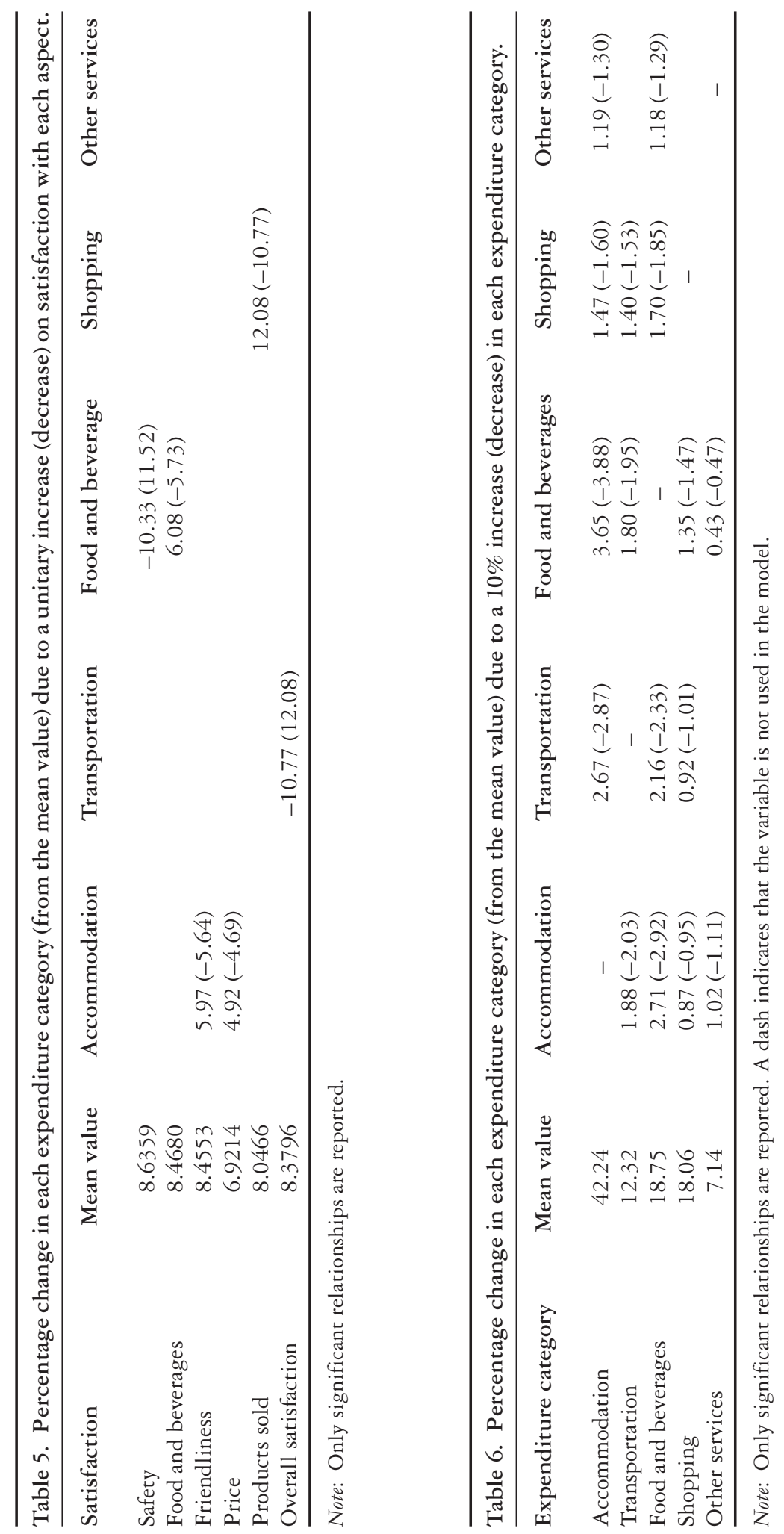
expenditure categories are positive and significant, implying that the size of one category is affected by the size of other categories. Tables 4 and 6 can be read for both an increase and a decrease in the amount of money spent. As a consequence, the results of the model would indicate not only the influence of an increase but also the influence on the different expenditure categories by a decrease in each expenditure category. As shown in Table 6, generally, the more tourists spend on one category the more they will spend on other categories and, likewise, the less they spend in one category, the less they will spend on the other categories.

Specifically, the amount of money spent on accommodation and food and beverages is positively influenced by any percentage increase in all other expenditure categories. Similarly, accommodation and food and beverages are the two product categories that affect the size of the expenditure in all other product categories. The amount of money spent on food and beverages is first influenced by the amount spent on accommodation, and the amount spent on accommodation is first influenced by the amount spent on food and beverages. The expenditure on accommodation is further influenced by internal transportation, other services and shopping. Moreover, expenditure on food and beverages is further influenced by internal transportation, shopping and finally by the amount spent on other services. The amount spent on internal transportation is first influenced by the amount spent on accommodation, then by the amount spent on food and beverages, and finally by the amount spent on shopping. Similarly, the expenditure on shopping is influenced by the amount spent on food and beverages, accommodation and transportation. Finally, the amount spent on other services is equally influenced by the expenditure on accommodation and food and beverages.

\section{Influence of characteristics of both trip and visitors}

The number of nights spent at the destination, the number of cities visited during the trip and the number of repeated visits in Italy significantly affect the willingness to spend and the amount of money spent, both in the different expenditure categories and in the total budget spent. In particular, as reported in Table 2, the higher the number of nights spent at the destination, the lower the amount spent for the whole trip (for a one-day increase we expect to see a $3.2 \%$ decrease in the total visitor spending). As reported in Tables 3 and 4, the higher the number of nights spent at the destination, the higher the willingness to pay for accommodation, while in a negative way, the higher the number of nights spent at the destination, the lower the average amount spent per night both for the whole trip and in each expenditure category, with shopping being the most affected, followed by accommodation, internal transportation, food and beverages and other services (see Table A2 in the Appendix for the estimated percentage variation). As Table 2 reports, the higher the number of repeat visits, the lower the total expenditure: first-time visitors and visitors who have already visited Italy up to 5 times, respectively, spend $29.6 \%$ and $14.4 \%$ less then visitors who have already visited Italy more than 5 times in the past. As regards the effect of the repeat visits on each expenditure category (see Tables 3, 4 and Table A2 in the Appendix), those who are visiting Italy for the first time are much less willing to spend on other services and 
internal transportation, and only slightly less willing to spend on accommodation. When they take the decision to spend on internal transportation or shopping, they spend more than repeat visitors. Conversely, when they take the decision to spend on accommodation, they spend less than repeat visitors. In contrast, those who have already visited Italy up to five times in the past are more willing to spend on other services but less willing to spend on internal transportation and shopping; they spend more on other services but less on accommodation than other categories of visitors. Visitors who visit only one city during the trip spend less for the whole trip ( $36.3 \%$ less), are less willing to spend on food and beverages and shopping, and spend less on internal transportation.

As regards the composition of the travel group, we can observe (see Tables 3, 4 and Table A2 in the Appendix) that visitors who are travelling alone are less willing to spend on shopping and on other services, and spend less on other services than visitors travelling with a group but more on food and beverages.

As regards the demographic profile, the most relevant characteristic seems to be origin. As Table 2 shows, the lower the distance between the place of residence and the place visited, the lower the amount of money spent for the whole trip: Austrian (Austria is a neighbouring state to the Dolomite area) and German visitors spend less than visitors from other European countries (respectively, $60.6 \%$ and $25.5 \%$ less), while visitors from countries outside Europe are the ones who spend more for the whole trip (35.9\% more). Austrian and German visitors are less willing to spend for almost all expenditure categories, while visitors from countries outside Europe are more willing to spend on shopping and other services. Regarding the amount of money spent during the trip (see Table 4 and Table A2 in the Appendix), Austrian visitors spend more on shopping and food and beverages than other visitors, but less on all the other categories, while German visitors and visitors from outside Europe spend less, respectively, on other services and food and beverages than visitors from other European countries. The second, and last, relevant characteristic to affect both the willingness to pay and the amount of money spent in each expenditure category is age. In particular, younger visitors are more willing to spend on internal transportation, food and beverages and other services. Observing the influence of age on the second stage (the amount of money spent), we note that visitors younger than 35 spend less than older visitors on accommodation; the higher the age, the lower the amount spent on food and beverages; middleaged visitors (between 34 and 44) spend more on shopping than younger or older visitors.

\section{Discussion and conclusion}

The aim of this study was twofold: (a) to determine the influence of satisfaction with different attributes of the destination on tourists' spending behaviour; (b) to determine the dependence among different expenditure categories.

Although overall satisfaction with the destination exerts only a negative effect on the amount of money spent on transportation (very likely the more tourists are satisfied with the destination, the less they will travel around in search of new or different places), satisfaction with the different aspects of the 
destination exerts an influence on both the willingness to pay and the amount of money spent in the different expenditure categories. Particularly relevant is the relationship between the aspect with which tourists are satisfied (or dissatisfied) and the product category. Dis/satisfaction with food and beverages, for example, directly influences expenditure on food and beverages; similarly, dis/ satisfaction with products sold determines the amount of money spent on shopping and dis/satisfaction with the friendliness of the local people influences expenditure on accommodation. These results show that expenditure at the destination (and therefore the profit of the single services located at the destination) is intimately linked to the standard of the service offered. In a destination like the Dolomites, where the supply side is mainly composed of small enterprises in the hands of local people, destination mangers and planners should first of all promote among local hosts and hoteliers friendliness and cross-cultural understanding. Similarly, it should be communicated to the different service operators in the destination (for example, restaurateurs) that satisfaction (and therefore the standard of the service linked to price and customers' expectation) determines the amount of money spent on the business. Therefore, at the destination level, targeting high spenders is meaningless unless the service offered by the individual operators reaches the standards sought by the market segment. As an example, the area under analysis comprises a destination that was marketed as a luxury destination in the late 1950s and early 1960s because of the 1956 Winter Olympics, and up to the early 1990s because of films that were set there, leveraging in parallel the names of famous actors who visited the place for their holidays. It is still perceived as a luxury destination, but hotels and service providers have failed over the years to renovate and keep up with international luxury standards. The result is the current stagnation of the destination.

Furthermore, particularly noteworthy is the role of landscape. In previous studies satisfaction with elements like natural landscape, flora and fauna were seen to play a significant role in tourists' overall satisfaction (Pritchard and Havitz; 2006; Maunier and Camelis, 2013). In the present study satisfaction with the landscape positively affects the choice of tourists to spend on accommodation and transportation, and the total amount of money spent for the whole trip. This result should work as a warning to those tourist destinations where the maintenance of landscape and natural environment is partially neglected and left to the good will of private landowners. As most landowners are not part of the tourism sector, it is important that destination managers fully comprehend the effect of a beautiful and unspoilt natural environment on tourists' expenditure and start to cooperate with other sectors (such as farming) to ensure maintenance and enhancement of the natural environment.

The results of this study are in line with those of Kim et al (2010), Zhang et al (2010), Chen and Chang (2012), Bigné et al (2005) and Kim and Cha (2002), and confirm the theory that satisfaction is a predictor of expenditure. The study offers a further contribution to the literature by determining the relationship between satisfaction with the different aspects of the destination and the expenditure category incurred by the tourists.

In the literature review, we discussed the utility function by which tourists are able to rank goods and services and select the combination that offers them the best value at a certain level of budget. This theory assumes independence 
only among groups of commodities (that is, tourism versus other industries and services) as opposed to individual commodities (accommodation versus food and beverages, transportation, shopping and so forth). The results of this study show that the two most interlinked spending categories are accommodation and food and beverages in premises outside the accommodation: the variation of one produces a strong variation in the other. These results are noteworthy if we consider the negative variations. At a time of economic crises, the study demonstrates that, when tourists decide to spend less on accommodation, they will inevitably also economize on food and beverages and vice versa. Furthermore, accommodation and food and beverages also exert the strongest influence on all other spending categories. So, if tourists decide to save on accommodation and food and beverages, spending on all other tourism-related services will be negatively affected.

\section{References}

Agarnal, V.B., and Yochum, G.R. (2000), 'Determinants of tourist spending', in Woodside, A.G., Crouch, G.I., Mazanec, J.A., Oppermann, M., and Sakai, M.Y., eds, Consumer Psychology of Tourism, Hospitality and Leisure, Vol 1, CAB International, Wallingford, pp 311-330.

Alegre, J., and Garau, J. (2010), 'Tourist satisfaction and dissatisfaction', Annals of Tourism Research, Vol 37, No 1, pp 52-73.

Alegre, J., and Juaneda, C. (2006), 'Destination loyalty consumers' economic behavior', Annals of Tourism Research, Vol 33, No 3, pp 684-706.

Alegre, J., and Pou, L. (2004), 'Micro-economic determinants of the probability of tourism consumption', Tourism Economics, Vol 10, No 2, pp 125-144.

Alegre, J., Mateo, S., and Pou, L. (2013), 'Tourism participation and expenditure by Spanish households: the effects of the economic crisis and unemployment', Tourism Management, Vol 39, pp 37-49.

Amemiya, T. (1984), 'Tobit models: a survey', Journal of Econometrics, Vol 24, No 1, pp 3-26.

Anderson, E.W. (1996), 'Customer satisfaction and price tolerance', Marketing Letters, Vol 7, No 3, pp 265-274

Anderson, E.W., and Mittal, V. (2000), 'Strengthening the satisfaction-profit chain', Journal of Service Research, Vol 3, No 2, pp 107-120.

Anderson, E.W., Formell, C., and Lehmann, D.R. (1994), 'Customer satisfaction, market share, and profitability: findings from Sweden', Journal of Marketing, Vol 58, No 3, pp 53-66.

Anderson, E.W., Fornell, C., and Lehmann, D.R. (1997), 'Customer satisfaction, market share, and profitability: findings from Sweden', Journal of Marketing, Vol 58, pp 53-66.

Baker, D., and Crompton, J. (2000), 'Quality, satisfaction and behavioral intentions', Annals of Tourism Research, Vol 27, No 3, pp 785-804.

Banca d'Italia (2011), 'Turismo internazionale dell'Italia', Banca d'Italia (https://www.bancaditalia.it/ statistiche/tematiche/rapporti-estero/turismo-internazionale/).

Barquet, A., Brida, J.G., Osti, L., and Schubert, S. (2011), 'An analysis of tourists' expenditure on winter sports events through the Tobit censorate model', Tourism Economics, Vol 17, No 6, pP 1197-1217.

Belenkiy, M., and Riker, D. (2013), 'Modeling the international tourism expenditures of individual travelers', Journal of Travel Research, Vol 52, No 2, pp 202-211.

Bigné, J.E., Andreu, L., and Gnoth, J. (2005), 'The theme park experience: an analysis of pleasure, arousal and satisfaction', Tourism Management, Vol 26, pp 833-844.

Bilgic, A., Florkowski, W., Yoder, J., and Schreiner, D. (2008), 'Estimating fishing and hunting leisure spending shares in the United States', Tourism Management, Vol 29, pp 771-782.

Brida, J.G., and Scuderi, R. (2013), 'Determinants of tourist expenditure: a review of microeconometric models', Tourism Management Perspectives, Vol 6, pp 28-40.

Brida, J.G., Disegna, M., and Osti, L. (2012), 'The effect of authenticity on visitors' expenditure at cultural events', Current Issues in Tourism, Vol 16, No 3, pp 266--285.

Brida, J.G., Disegna, M., and Osti, L. (2013a), 'Visitors' expenditure behaviour at cultural events: the case of Christmas markets', Tourism Economics, Vol 19, No 5, pp 1173-1196. 
Brida, J.G., Disegna, M., and Scuderi, R. (2013b), 'Visitors to two types of museums: do expenditure patterns differ?', Tourism Economics, Vol 19, No 5, pp 1027-1047.

Byrne, P.J., Capps, O.Jr., and Saha, A. (1996), 'Analysis of food-away-from-home expenditure patterns for U.S. Households, 1982-89', American Journal of Agricultural Economics, Vol 78, pp 614-627.

Chadee, D., and Mattsson, G. (1996), 'An empirical assessment of customer satisfaction in tourism', The Service Industries Journal, Vol 16, No 3, pp 305-320.

Chang, K.L., Chen, C.M., and Meyer, T. (2013), 'A comparison study of travel expenditure and consumption choices between first-time and repeat visitors', Tourism Management, Vol 35, pp 275277.

Chen, C.-M., and Chang, K.-L. (2012), 'The influence of travel agents on travel expenditures', Annals of Tourism Research, Vol 32, No 2, pp 1258-1263.

Cragg, J. (1971), 'Some statistical models for limited dependent variables with application to the demand for durable goods', Econometrica, Vol 39, pp 829-844.

Craggs, R., and Schofield, P. (2009), 'Expenditure-based segmentation and visitor profiling at The Quays in Salford, UK', Tourism Economics, Vol 15, No 1, pp 243-260.

Davies, B., and Morgan, J. (1996), 'Family expenditure on hotels and holidays', Annals of Tourism Research, Vol 19, No 4, pp 691-699.

Deaton, A., and Muellbauer, J. (1980), Economics and Consumer Behavior, Cambridge University Press, Cambridge.

Divisekera, S. (2010), 'Economics of tourist's consumption behavior: some evidence from Australia', Tourism Management, Vol 31, pp 629-636.

Downward, P., and Lumsdon, L. (2000), 'The demand for day-visits: an analysis of visitor spending', Tourism Economics, Vol 6, No 3, pp 251-261.

Downward, P., and Lumsdon, L. (2003), 'Beyond the demand for day-visits: an analysis of visitor spending', Tourism Economics, Vol 9, No 1, pp 67-76.

Enright, M.J., and Newton, J. (2004), 'Tourism destination competitiveness: a quantitative approach', Tourism Management, Vol 25, No 6, pp 777-788.

Fuchs, M., and Weiermair, K. (2004), 'Destination benchmarking: an indicator-system's potential for exploring guest satisfaction', Journal of Travel Research, Vol 42, No 3, pp 212-225.

Godbey, G., and Graefe, A. (1991), 'Repeat tourism, play and monetary spending', Annals of Tourism Research, Vol 18, No 2, pp 213-225.(

Gyte, D., and Phelps, A. (1989), 'Patterns of destination repeat business: British tourists in Mallorca, Spain', Journal of Travel Research, Vol 28, No 1, pp 24-28.

Heckman, J.J. (1976), 'Sample selection bias as a specification error', Econometrica, Vol 47, No 1, pp 153-161.

Heien, D., and Wessells, C. (1990), 'Demand system estimation with micro data: a censored regression approach', Journal of Business E Economic Statistics, Vol 8, No 3, pp 356-371.

Homburg, C., Koschate, N., and Hoyer, W.D. (2005), 'Do satisfied customers really pay more? A study of the relationship between customers satisfaction and willingness to pay', Journal of Marketing, Vol 69, pp 84-96.

Hong, G.S., Kim, S.Y., and Lee, J. (1999), 'Travel expenditure patterns of elderly households in the US', Tourism Recreation Journal, Vol 24, No 1, pp 43-52.

Hui, T., Wan, D., and Ho, A. (2007), 'Tourists' satisfaction, recommendation and revisiting Singapore', Tourism Management, Vol 28, No 4, pp 965-975.

Hung, W.-T., Shang, J.-K., and Wang, F.-C. (2012), 'Another look at the determinants of tourism expenditure', Annals of Tourism Research, Vol 39, No 1, pp 495-498.

Jang, S., and Ham, S. (2009), 'A double-hurdle analysis of travel expenditure: baby boomer seniors versus older seniors', Tourism Management, Vol 30, No 3, pp 372-380.

Jang, S.C.S., Bai, B., Hong, G.S., and O'Leary, J.T. (2004), 'Understanding travel expenditure patterns: a study of Japanese pleasure travelers to the Unitied States by income level', Tourism Management, Vol 25, No 3, pp 331-341.

Kim, S.S., Prindeaux, B., and Chon, K. (2010), 'A comparison of results of three statistical methods to understand the determinants of festival participants' expenditures', International Journal of Hospitality Management, Vol 29, pp 297-307.

Kim, W.G., and Cha, Y. (2002), 'Antecedents and consequence of relationship quality in hotel industry', International Journal of Hospitality Management, Vol 21, No 4, pp 321-338.

Kim, W.G., Kim, T.T., Gazzoli, G., Park, Y., Kim, S.H., and Park, S.S. (2011), 'Factors affecting the travel expenditure of visitors to Macau, China', Tourism Economics, Vol 17, No 4, pp 857-883. 
Klaus, P. (1985), 'Quality epiphenomenon: the conceptual understanding of quality in face-to-face service encounters', in Czepiel, J.A., Solomon, M.R., and Surprenant, C.F., eds, The Service Encounter: Managing Employee/Customer Interaction in Service Business, Lexington Books, Lexington, MA, pp 17-33.

Kozak, M., and Rimmington, M., (2000), 'Tourist satisfaction with Mallorca, Spain, as an off-season holiday destination', Journal of Travel Research, Vol 38, No 3, pp 260-269.

Laesser, C., and Crouch, G.I. (2006), 'Segmenting markets by travel expenditure patterns: the case of international visitors to Australia', Journal of Travel Research, Vol 44, pp 397-406.

Lee, C. (2001), 'Determinants of recreational boater expenditures on trips', Tourism Management, Vol 22, No 6, pp 659-667.

Legoherel, P. (1998), 'Toward a market segmentation of the tourism trade: expenditure levels and consumer behavior instability', Journal of Travel and Tourism Marketing, Vol 7, No 3, pp 19-39.

Lehto, X.Y., O'Leary, J.T., and Morrison, A.M. (2004), 'The effect of prior experience on vacation behavior', Annals of Tourism Research, Vol 31, No 4, pp 801-818.

Leones, J., Codby, B., and Crandall, K. (1998), 'Tracking expenditures of the elusive nature tourists of Southeastern Arisona', Journal of Travel Research, Vol 36, No 3, pp 56-64.

Lim, C. (2006), 'A survey of tourism demand modelling practice: Issues and implications', in Dwyer, L., and Forsyth, P., eds, International Handbook on the Economics of Tourism, Edward Elgar Publishing, Cheltenham, pp 45-72.

Maddala, G.S. (1983), Limited-Dependent and Qualitative Variables in Econometrics, Cambridge University Press, Cambridge.

Manrique, J., and Jensen, H.H. (1997), 'Spanish household demand for convenience meat products', Agribusiness, Vol 13, No 6, pp 579-586.

Marzetti Dall'Aste Brandolini S., and Disegna, M. (2012), 'Demand for the quality conservation of Venice, Italy, according to different nationalities', Tourism Economics, Vol 18, No 5, pp 1019-1050, DOI: $10.5367 /$ te.2012.0157.

Maunier, C., and Camelis, C. (2013), 'Towards an identification of elements contributing to satisfaction with the tourism experience', Journal of Vacation Marketing, Vol 19, No 1, pp 19-39.

Mok, C., and Iverson, T.J. (2000), 'Expenditure-based segmentation: Taiwanese tourists to Guam', Tourism Management, Vol 21, pp 299-305.

Munier, C., and Camelis, C. (2013), 'Toward an identification of elements contributing to satisfaction with the tourism experience', Journal of Vacation Marketing, Vol 19, No 1, pp 19-39.

Neal, J.D., and Gursoy, D. (2008), 'A multifaceted analysis of tourism satisfaction', Journal of Travel Research, Vol 47, pp 53-62.

Oliver, R.L. (1980), 'A cognitive model of the antecedents and consequences of satisfaction decisions', Journal of Marketing Research, Vol 17, No 4, pp 460-469.

Oliver, R., and Burke, R. (1999), 'Expectation processes in satisfaction formation: a field study', Journal of Service Research, Vol 1, No 3, pp 196-214.

Oliver, R., and Swan, J. (1989), 'Equity and disconfirmation perceptions as influences on merchant and product satisfaction', Journal of Consumer Research, Vol 16, No 3, pp 372-383.

Oppermann, M. (1996), 'Visitation of tourism attractions and tourist expenditure patterns - repeat versus first-time visitors', Asia Pacific Journal of Tourism Research, Vol 1, No 1, pp 61-68.

Oppermann, M. (1997), 'First-time and repeat visitors to New Zealand', Tourism Management, Vol 18, pp 177-181.

Pritchard, M.P., and Havitz, M.E. (2006), 'Destination appraisal. An analysis of critical incidents', Annals of Tourism Research, Vol 33, No 1, pp 25-46.

Pudney, S. (1989), Modelling Individual Choice: the Econometrics of corners, Kinks, and Holes, Basil Blackwell, London.

Ryan, C. (2003), Recreational Tourism: Demand and Impacts, Channel View Publications, Clevedon.

Sirgy, J. (1984), 'A social cognition model of consumer satisfaction/dissatisfaction', Psychology $\mathcal{E}$ Marketing, Vol 1, No 2, pp 27-44.

Syriopoulos, T., and Sinclair, M. (1993), 'An econometric study of tourism demand: the aids model of us and European tourism in Mediterranean countries', Applied Economics, Vol 25, pp 15411552.

Thompson, K., and Schofield, P. (2007), 'An investigation of the relationship between public transport performance and destination satisfaction', Journal of Transport Geography, Vol 15, No 2, pp $136-144$.

Tobin, J. (1958), 'Estimation of relationships for limited dependent variables', Econometrica, Vol 26, No 1, pp 24-36. 
Tribe J. (2005), The Economics of recreation, Leisure \& Tourism, 3rd edn, Elsevier, Amsterdam.

Wang, Y., and Davidson, M.C.G. (2010), 'A review of micro-analyses of tourist expenditure', Current Issues in Tourism, Vol 13, No 6, pp 507-524.

Weagley, R.O., and Huh, E. (2004), 'Leisure expenditures of retired and near-retired households', Journal of Leisure Research, Vol 36, No 1, pp 101-127.

White, H. (1980), 'A heteroscedasticity-consistent covariance matrix estimator and a direct test for heteroscedasticity', Econometrica, Vol 48, No 4, pp 817-838.

Wu, L., Zhang, J., and Fujiwara, A. (2013), 'Tourism participation and expenditure behaviour: analysis using a Scobit Based Discrete-Continuous choice model', Annals of Tourism Research, Vol 40, pp 1-17.

Zhang, L., Qu, H., and Ma, J.(E.) (2010), 'Examining the relationship of exhibition attendees' satisfaction and expenditure: the case of two major exhibitions in China', Journal of Convention E Event Tourism, Vol 11, No 2, pp 100-118.

Zheng, B., and Zhang, Y. (2011), 'Household expenditures for leisure tourism in the USA, 1996 and 2006', International Journal of Tourism Research, Vol 15, No 2, pp 197-208. 
TOURISM ECONOMICS

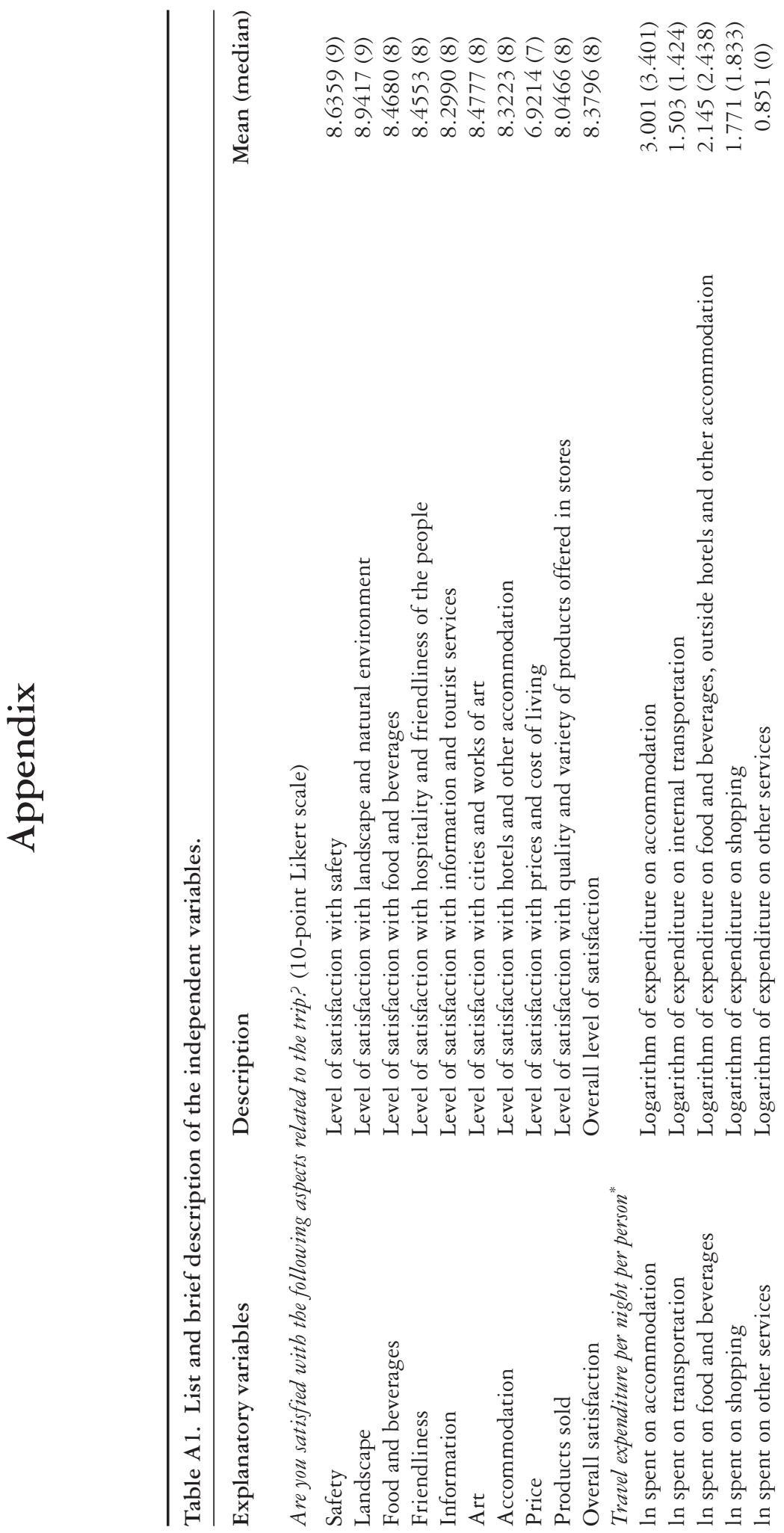




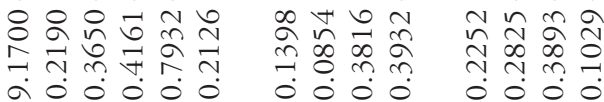

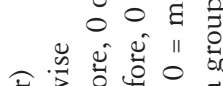

के

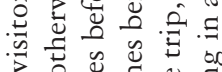

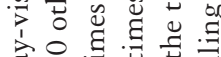

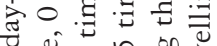

"

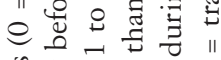

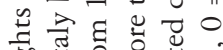

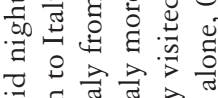

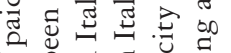

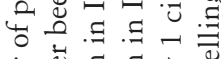
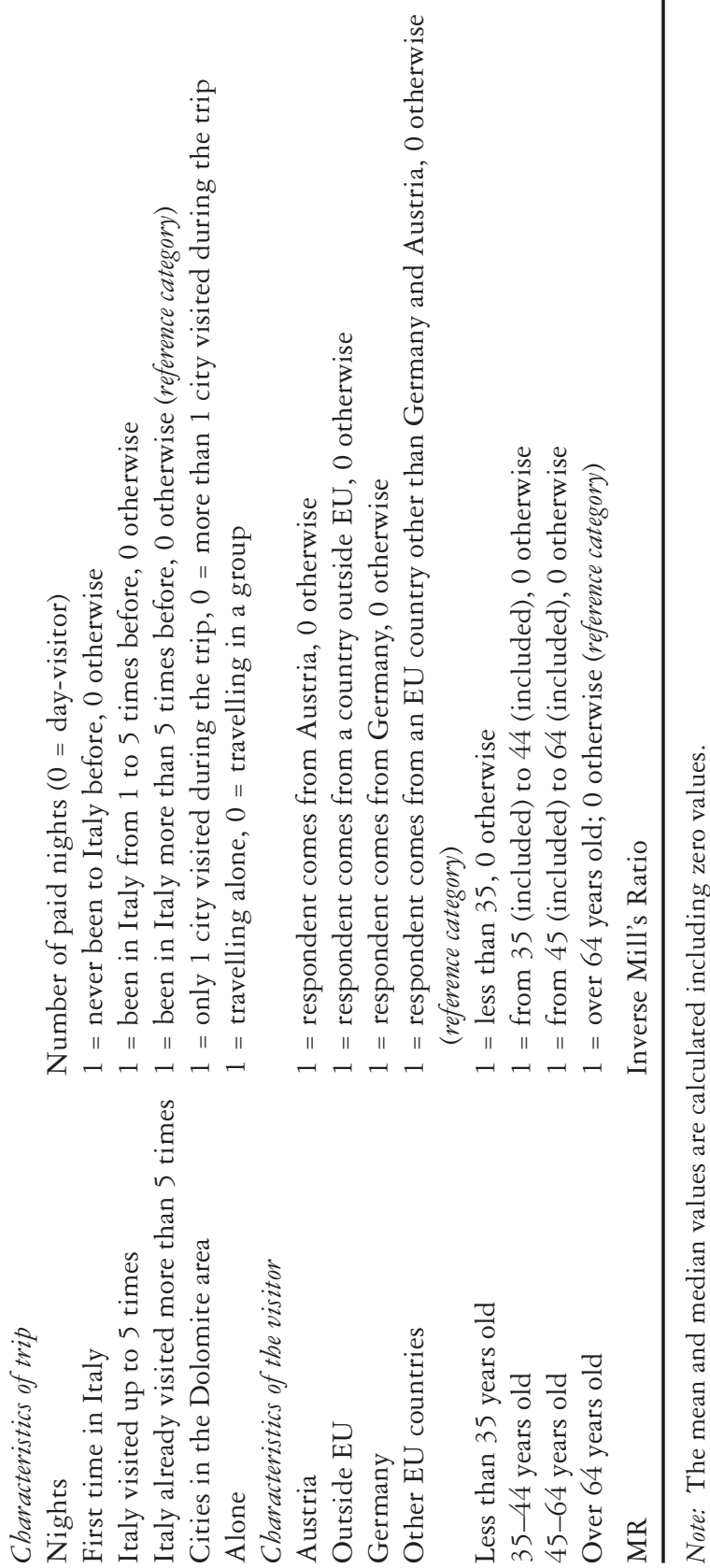
TOURISM ECONOMICS

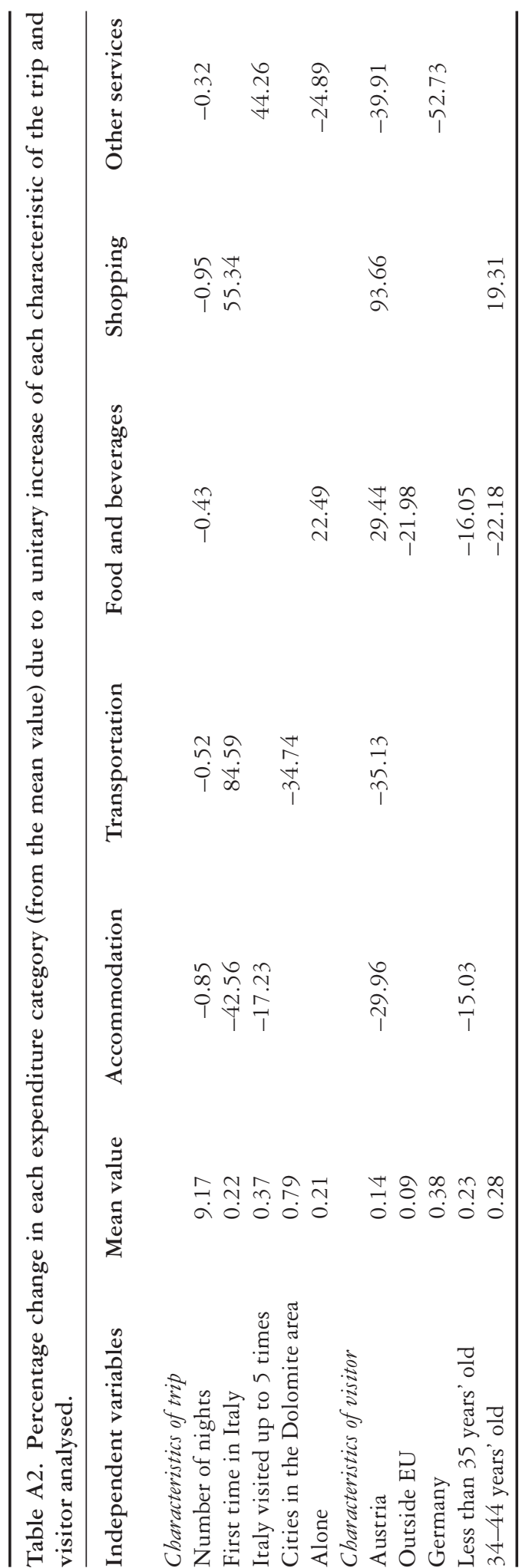

